\title{
The inactivation of factor VIII in vitro
}

Citation for published version (APA):

Stibbe, J., Hemker, H. C., \& van Creveld, S. (1972). The inactivation of factor VIII in vitro. Thrombosis et diathesis haemorrhagica, 27(1), 43-58. https://doi.org/10.1055/S-0038-1649008

Document status and date:

Published: 29/02/1972

DOI:

10.1055/S-0038-1649008

Document Version:

Other version

\section{Please check the document version of this publication:}

- A submitted manuscript is the version of the article upon submission and before peer-review. There can be important differences between the submitted version and the official published version of record.

People interested in the research are advised to contact the author for the final version of the publication, or visit the DOI to the publisher's website.

- The final author version and the galley proof are versions of the publication after peer review.

- The final published version features the final layout of the paper including the volume, issue and page numbers.

Link to publication

\footnotetext{
General rights rights.

- You may freely distribute the URL identifying the publication in the public portal. please follow below link for the End User Agreement:

www.umlib.nl/taverne-license

Take down policy

If you believe that this document breaches copyright please contact us at:

repository@maastrichtuniversity.nl

providing details and we will investigate your claim.
}

Copyright and moral rights for the publications made accessible in the public portal are retained by the authors and/or other copyright owners and it is a condition of accessing publications that users recognise and abide by the legal requirements associated with these

- Users may download and print one copy of any publication from the public portal for the purpose of private study or research.

- You may not further distribute the material or use it for any profit-making activity or commercial gain

If the publication is distributed under the terms of Article $25 \mathrm{fa}$ of the Dutch Copyright Act, indicated by the "Taverne" license above, 


\section{THROMBOSIS ET DIATHESIS HAEMORRHAGICA}

EDITORES : K. M. BRINKHOUS, CHAPEL HILL; E. DEUTSCH, WIEN; R. GROSS, KÖLN; J. E. JORPES, STOCKHOLM; F. KOLLER, BASEL; J. ROSKAM, LIËGE; SOL SHERRY, PHILADELPHIA; J.-P. SOULIER, PARIS; I. S. WRIGHT, NEW YORK

\section{The Inactivation of Factor VIII in Vitro}

J. StribBe**, H. C. Hemker*** and S. v. Creveld*

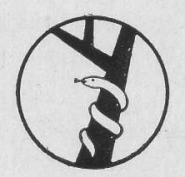

F. K. SCHATTAUER VERLAG - STUTTGART-NEW YORK 
Antihemophilic factor A (AHF) or blood coagulation factor VIII is defined as the plasma factor, which activity is deficient or absent in haemophilia A. Haemophilia A is defined as a clinical picture of a haemorrhagic diathesis with a recessive sex-linked inheritance, distinguishable from haemophilia B and other congenital haemorrhagic diatheses. This definition of factor VIIT leaves unanswered all questions of biochemical and physico-chemical characterisation of the molecule(s) that is (are) responsible for the factor VIII activity. On basis of this definition the deficiency of a plasmatic coagulation factor found in most patients with von Willebrand's disease is to be regarded as a deficiency of factor VIII. This statement does not, however, state whether the deficiency in haemophilia A and von Willebrand's plasma has the same molecular basis or not. Mutatis mutandis the same holds for the increased factor VIII-(like) activity found after exercise or adrenaline injection; or the increased activity found in late pregnaney.

It has been found by different authors that when plasma is stored, its factor VIII activity initially decreases fast, but becomes appreciably more stable after some time $(1,4,10,13,18,25)$.

We too found $(19,20)$, that in normal citrated plasma incubated at $37^{\circ} \mathrm{C}$ at $\mathrm{pH} 7.8$ the factor VIII activity drops to about $50 \%$ of its initial value during the first $8-12 \mathrm{~h}$ and that during the following 4 days practically no further drop in activity is found. This loss of factor VIII activity cannot be the result of a random molecular degradation (see also Fig. 1) as would be expected to occur when a first order denaturation reaction was the cause of the inactivation. It is the aim of this article to further explore the reason for this phenomenon.

The inactivation of factor VIII in vitro and the experimental conditions that influence it are of practical and theoretical importance because :

1. At preparation and storage of plasma or of concentrates of factor VIII, used for the management of haemophilic bleeding, one of the handicaps is the lability of factor VIII. Prevention of the rapid initial inactivation of factor VIII might have considerable advantages for the treatment of haemophilia A.

2. Following intravenous injection of normal plasma or factor VIII concentrates to patients with haemophilia A the factor VIII activity in the circulating blood dis-

*) This work was carried out and nearly finished under the supervision of the late Prof. van Creveld. His much regretted death in march 1971 made that he could not help us with the final form of the publication. We have listed him as the senior author, as we would have done during his lifetime, but now we do this in grateful remembrance of a pioneer in biomedical chemistry and an inspiring teacher. Any mistake or misinterpretation of the experiments of course is our sole responsibility. J. S., H. C. H.

**) Department of Haemostasis and Thrombosis Research, Academic Hospital Dykzigt, Rotterdam, The Netherlands.

***) Laboratories for Coagulation and Cardiovascular Biochemistry, University Hospital, Leiden, The Netherlands.

Thrombos. Diathes. haemorrh. (Stuttg.) 
appears in a biphasic way. The initial rapid phase is usually interpreted as being due to equilibration between the intravascular and extravascular compartments while the subsequent slower phase is attributed to biological degradation. After observing a biphasic disappearance curve in vitro, the question arises wether the same process underlying the in vitro phenomenon might also play a role in vivo, but is masked by the equilibration with the extravascular compartment.

3. Analysis of this biphasic disappearance curve of factor VIII in vitro may give us information on the molecular properties of this clotting factor. Preferably postulates on such properties should fit in with observations on other known modifications of factor VIII activity such as e.g. occur in von Willebrand's disease. For these reasons we investigated the inactivation of factor VIII in vitro, and the way it was influenced by temperature, $\mathrm{pH}$, Ca-ion concentration and the presence of other clotting factors.

\section{Materials and Methods}

Collection of blood. Blood was collected by venipuncture in siliconized glass tubes in one-tenth its volume of $3.2 \%$ sodium citrate $2 \mathrm{H}_{2} \mathrm{O}$. The samples were immediately centrifuged two times for $10 \mathrm{~min}$ at $1000 \mathrm{~g}$ and room temperature. The plasma samples were used immediately for the experiments. The platelet count of this plasma as a rule was between 80,000 and 120,000 per $\mathrm{mm}^{3}$.

Resinplasma used for the experiments after treatment of the plasma with $\mathrm{BaSO}_{4}$ to adsorb factor VII, IX, X and II was prepared with Dowex $50 \mathrm{Wx12,} \mathrm{20-50} \mathrm{mesh} \mathrm{Fluka} \mathrm{AG.} \mathrm{The} \mathrm{blood}$ passed directly from the vein through the resin column into a siliconized bottle which was kept at melting ice. The bottle was centrifuged twice at $1800 \mathrm{~g}$ and $4^{\circ} \mathrm{C}$. No calcium concentration measured in this plasma.

For the experiments on the influence of the calcium concentration on factor VIII the Resinplasma was prepared using Fenwal Bloodpack Ion Exchange, JB-2 (Fenwal Laboratories, Morton Grove, Tllinois, U.S.A.). Otherwise the blood was treated in the same way. The calciumconcentration of this Resinplasma was $0.13 \mathrm{mmol} / \mathrm{l}$.

To follow the inactivation of factor VIII in vitro the plasma was incubated in siliconized tubes or plastic bags. The standard conditions being citrated plasma, $37^{\circ} \mathrm{C}$ and $\mathrm{pH} 7.8$.

At regular intervals two samples were taken and stored at $-25^{\circ} \mathrm{C}$ until assayed for factor VIII. Usually the samples were stored only for some days and never longer than 1 week. Generally samples were taken at the beginning of the incubation of the plasma and after about 1, 3, 6, 8, 24 and $28 \mathrm{~h}$. In some experiments incubation and sampling was continued for several days. To exclude experiments at each of these incubation intervals one sample was assayed for factor VIII immediately without freezing while an other sample was frozen

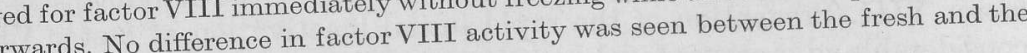
frozen samples.

Factor VIII was assayed by a one stage method according to den Ottolander and Bleyenberg (12) with some modifications using citrated (3.2\%) plasma from a severe hemophilia-A patient as a substrate. During the assay all reagents were kept on an ice bath.

The test was performed as follows:

$0.1 \mathrm{ml}$ of haemophilia-A plasma.

$0.1 \mathrm{ml}$ of test plasma diluted $1: 10$ and $1: 100$ in veronal buffer $\mathrm{pH} 7.42$.

$0.1 \mathrm{ml}$ of a suspension of dried human platelets (Behring Werke) in distilled water.

$0.1 \mathrm{ml}$ glass wool activated normal serum $(200-350 \mathrm{mg}$ glass wool per $\mathrm{ml}$ serum, for $7 \mathrm{~min}$ thoroughly mixed with the serum. The glasswool was then removed by centrifuging for $5 \mathrm{~min}$ at $2100 \mathrm{~g}$ and the serum diluted $1: 5$ in veronal buffer $\mathrm{pH} 7.42$ ).

The mixture is incubated for $30 \mathrm{sec}$ at $37^{\circ} \mathrm{C}$ and then $0.1 \mathrm{ml} \mathrm{CaCl}{ }_{2} 0.025 \mathrm{M}$ was added and the clotting time measured.

in the same way as factor VIII, using factor IX deficient plasma instead factor VIII deficient plasma and factor IX deficient serum instead of normal serum. 
only one process. For this reason plasma was incubated first at $37^{\circ} \mathrm{C}$, pH 7.8 for $24 \mathrm{~h}$ after which the first process would be terminated and then the plasma was divided into three parts. One part was left at $37^{\circ} \mathrm{C}$ and the other two parts were incubated further at 45 and $50^{\circ} \mathrm{C}$ resp. (Fig. 3).

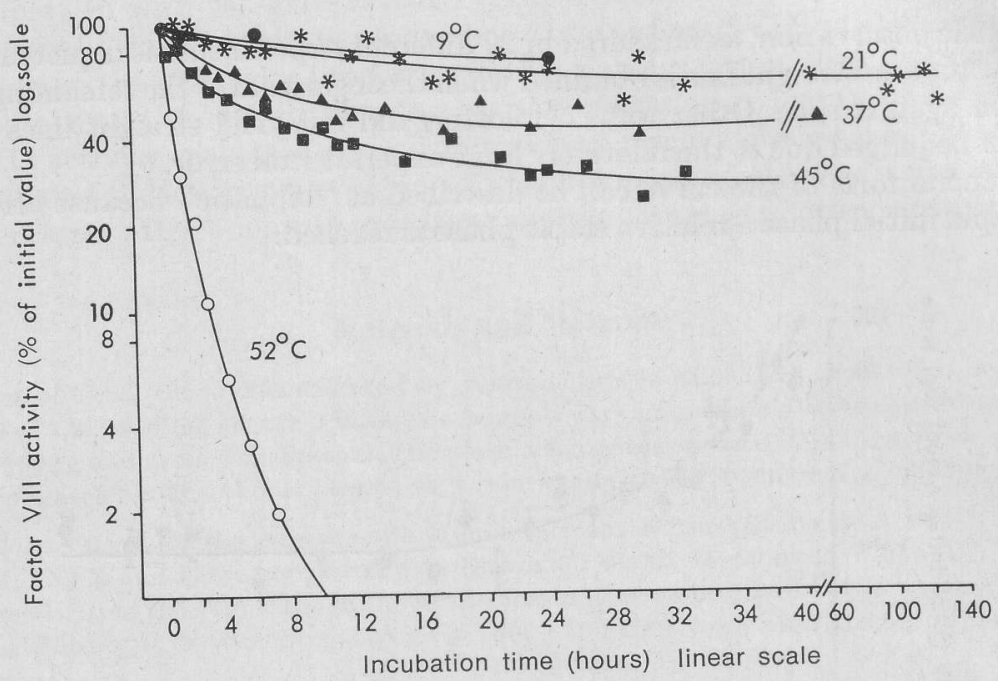

Fig. 2. The inactivation of factor VIII in normal citrated plasma at different temperatures and a constant $\mathrm{pH}$ of 7.8. Each curve is the mean of at least 3 experiments.

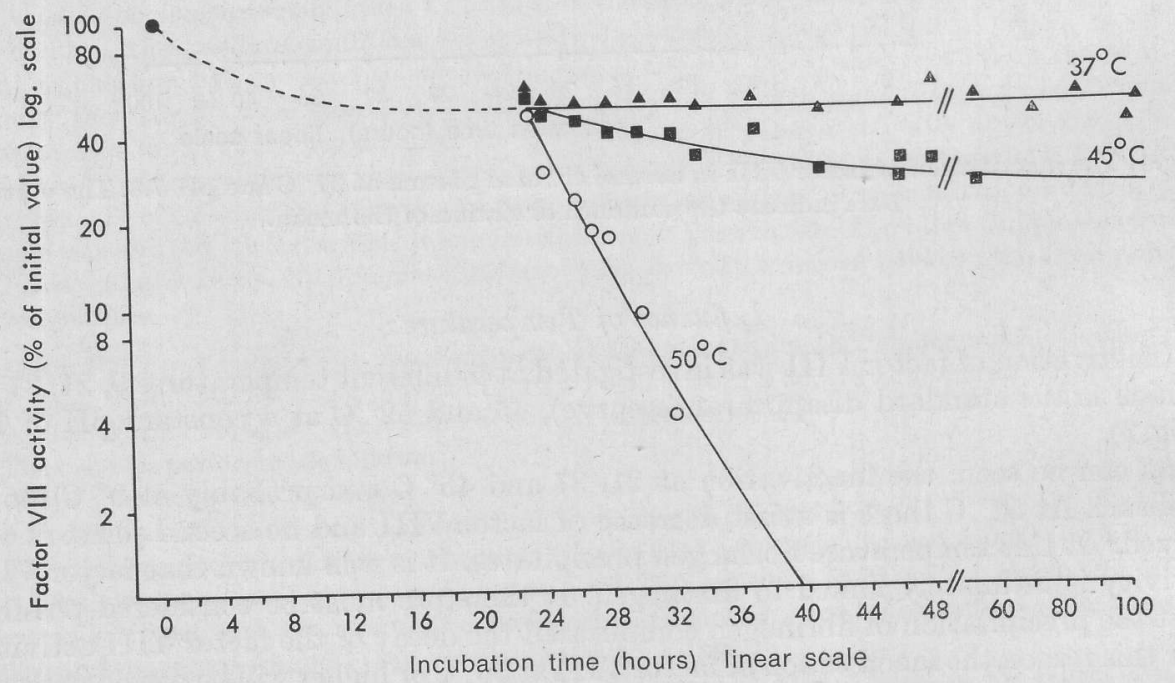

Fig. 3. The inactivation of factor VIII in normal citrated plasma that has been incubated at $37^{\circ} \mathrm{C}$ for $24 \mathrm{~h}$ after which time the plasma was incubated further at different temperatures and constant $\mathrm{pH}$ 7.8. See text. Each curve is the mean of 3 experiments. 


\section{Influence of $\mathrm{pH}$}

The influence of $\mathrm{pH}$ on the stability of factor VIII in vitro has been investigated by many authors (see discussion). We investigated the factor VIII inactivation at 3 different $\mathrm{pH}$ 's $(6.4,7.8,8.5)$ (Fig. 4$)$. The $\mathrm{pH}$ was altered by the addition of $\mathrm{HCl} 0.5 \mathrm{~N}$ or $\mathrm{NaOH} 0.5 \mathrm{~N}$.

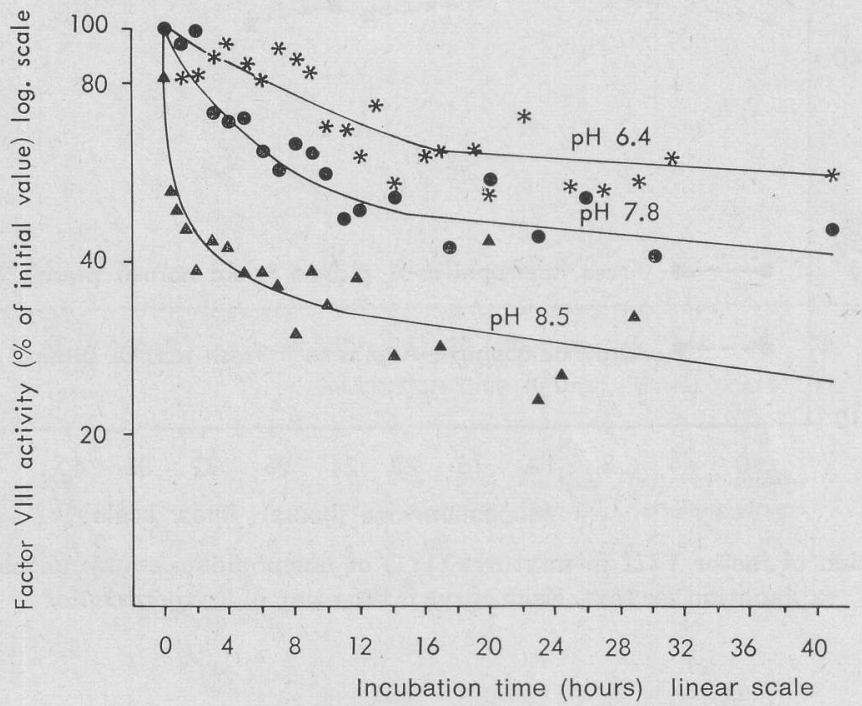

Fig.4. The inactivation of factor VIII activity at $37^{\circ} \mathrm{C}$ and different $\mathrm{pH}$. Fach eurve is the mean of 3 experiments.

At lower pH the inactivation of factor VIII in the first phase was obviously slower and the level of the second phase maintained at a higher factor VIII activity. Lowering the $\mathrm{pH}$ does influence the dissociation of Ca-citrate, so that more $\mathrm{Ca}^{++}$ions are present. As will be seen later, $\mathrm{Ca}^{++}$influences the inactivation of factor VIII so that the influence of $\mathrm{pH}$ changes in citrate plasma may be partly accounted for by changes in $\mathrm{Ca}^{++}$concentration.

\section{Influence of Other Coagulation Factors}

It may be possible that during collection of the blood or during incubation of the plasma one or more clotting factors or an intermediate product has some influence on the inactivation of factor VIII. The most simple way to investigate this is to observe the inactivation of factor VIII in the absence of one or more other coagulation factors.

If citrated plasma contains a hypothetical substance which influences the inactivation of factor VIII and which is independent of factor VIII, it may be supposed to be present in haemophilic A plasma.

Investigation of the inactivation of factor VIII in a mixture $(1: 1)$ of:

a) fresh haemophilic A plasma and old normal plasma $\left(24 \mathrm{~h}, 37^{\circ} \mathrm{C}, \mathrm{pH} 7.8\right)$ and

b) old haemophilic A plasma $\left(24 \mathrm{~h}, 37^{\circ} \mathrm{C}, \mathrm{pH} 7.8\right)$ and fresh normal plasma is shown in Fig. 5. The haemophilic A plasma does not seem to have any influence. 


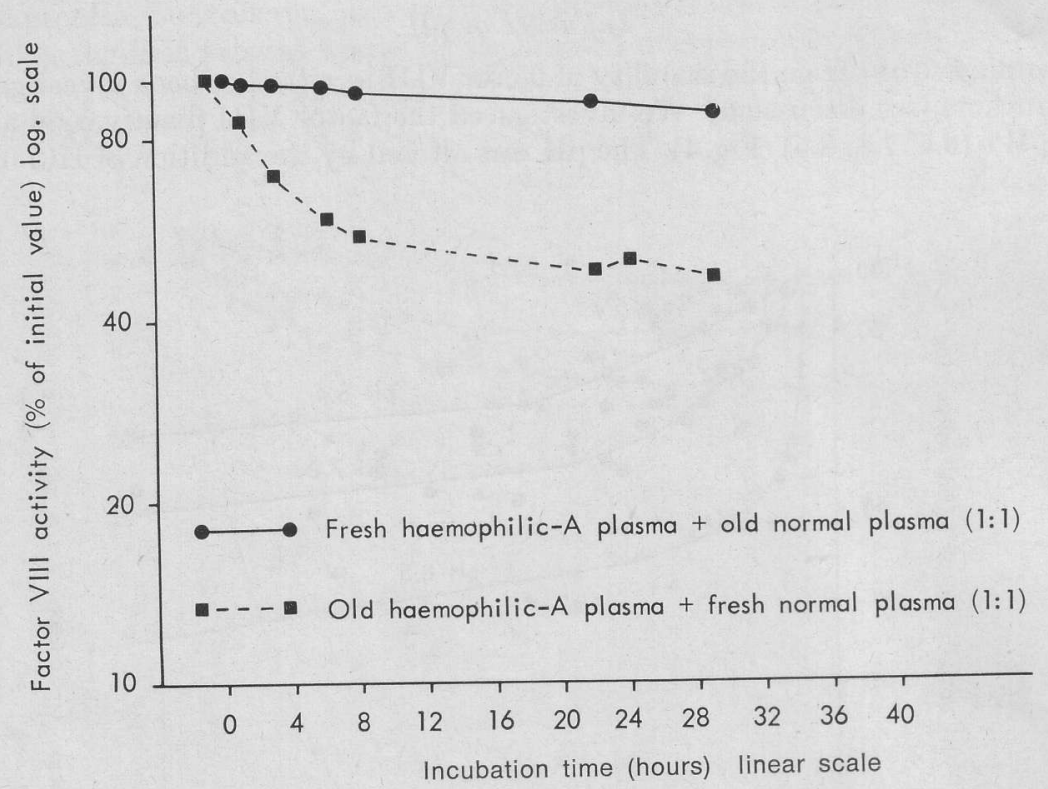

Fig.5. Inactivation of factor VIII in mixtures $(1: 1)$ of haemophilic-A and normal plasma. For explanation see text. Each curve is the mean of 3 experiments.

For the investigation of a possible influence of factor XII, IX and V the plasma was used of patients with a severe (XII, IX) or moderate deficiency $(\mathrm{V}, 3-5 \%$ of normal) in these factors. The influence of contact activation was also investigated by incubating normal plasma in non-siliconized glass. In all cases the course of factor VIII inactivation was indistinguishable from that in normal plasma (Fig. 6).

The influence of the factors II, VII, IX and X was investigated in resinplasma treated with $\mathrm{BaSO}_{4}$ so as to remove these factors to obtain levels of less than $2 \%$. Factor VIII activity was not influenced by treatment with $\mathrm{BaSO}_{4}$. The $\mathrm{pH}$ of the resinplasma was 7.8. The inactivation of the factor VIII in the resinplasma and in resinplasma treated with $\mathrm{BaSO}_{4}$ was the same as in normal citrated plasma (Fig. 7).

\section{Blood Platelets}

The citrated plasma used for the inactivation studies of factor VIII contains $80,000-120,000$ platelets $/ \mathrm{mm}^{3}$. The factor VIII level in this plasma is $100 \%$ by definition. Platelets have absorbed some factor VIII onto their surface $(3,24)$. When platelets were removed $\left(500-2000\right.$ platelets $\left./ \mathrm{mm}^{3}\right)$ factor VIII activity was found to be $81 \%$ of normal. Inactivation of factor VIII in platelet-poor plasma was the same as in platelet-rich plasma (Fig. 7).

\section{Fibrinogen}

As no patients with afibrinogenaemia were available, the influence of factor I could not be investigated. High fibrinogen levels $(700-900 \mathrm{mg} \%$ ) did not seem to influence the inactivation of factor VIII. 


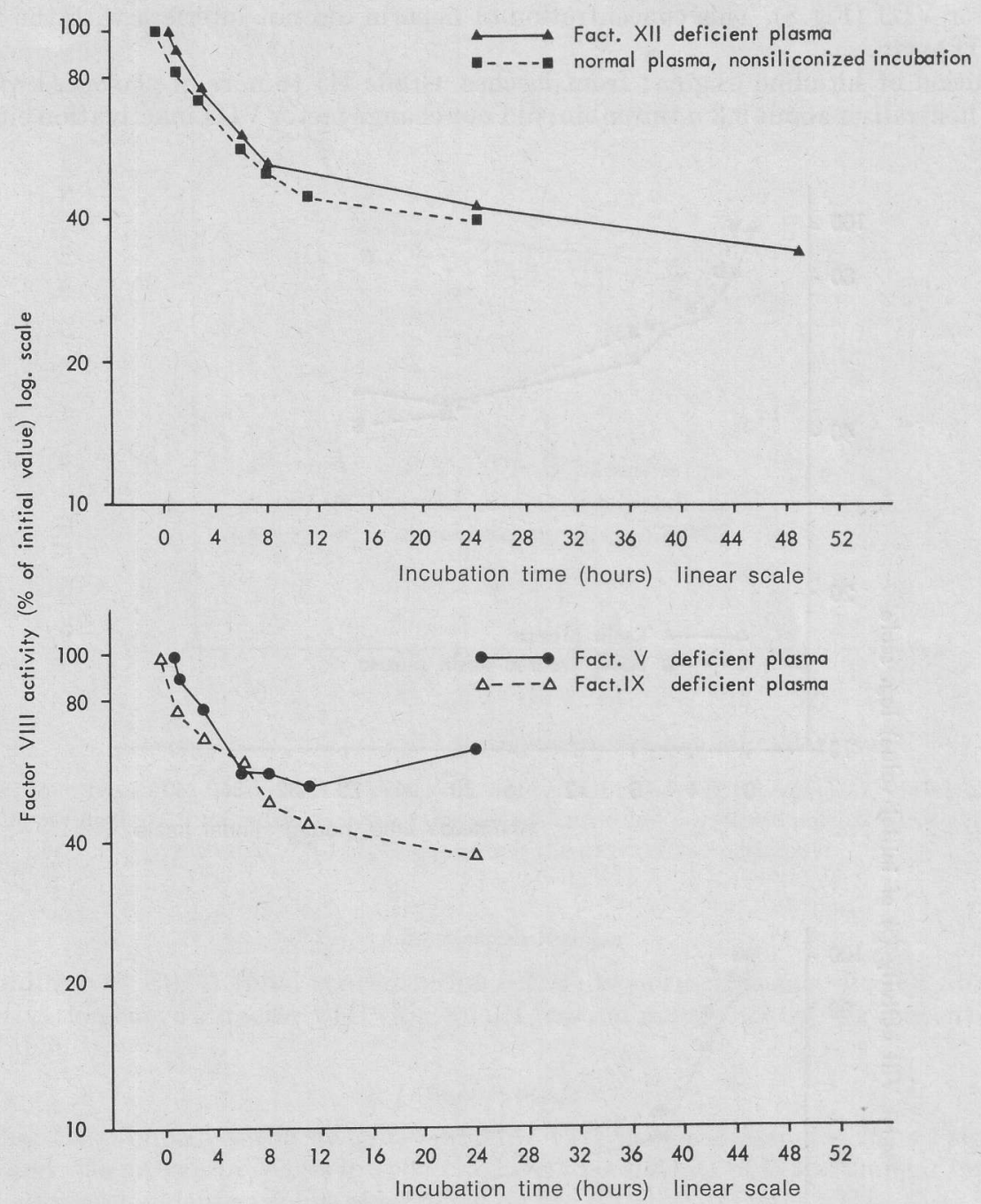

Fig.6. Inactivation of factor VIII in plasmas deficient in factor XII, IX, or V and in normal plasma incubated in non-siliconized glass tubes. Each curve is the mean of 3 experiments.

\section{Thrombin}

Trace amounts of thrombin are known to activate factor VIII $(15,16)$. Higher concentrations of thrombin destroy factor VIII (22). As the same rate of factor VIII inactivation was found in plasma deficient in the factors XII, IX, or $V$, as well as in $\mathrm{BaSO}_{4}$ adsorbed plasma and in platelet-poor plasma as in normal plasma, a role of thrombin becomes very improbable under the conditions in our experiments. According to Rizza and Walker (17) heparin $(0.075 \mathrm{u} / \mathrm{ml})$ ean prevent the inactivation of factor VIII by thrombin $(0.15 \mathrm{u} / \mathrm{ml})$. The addition of heparin to normal platelet-poor citrated plasma (final concentration $0.075 \mathrm{u} / \mathrm{ml}$ ), did not change the inactivation curve 


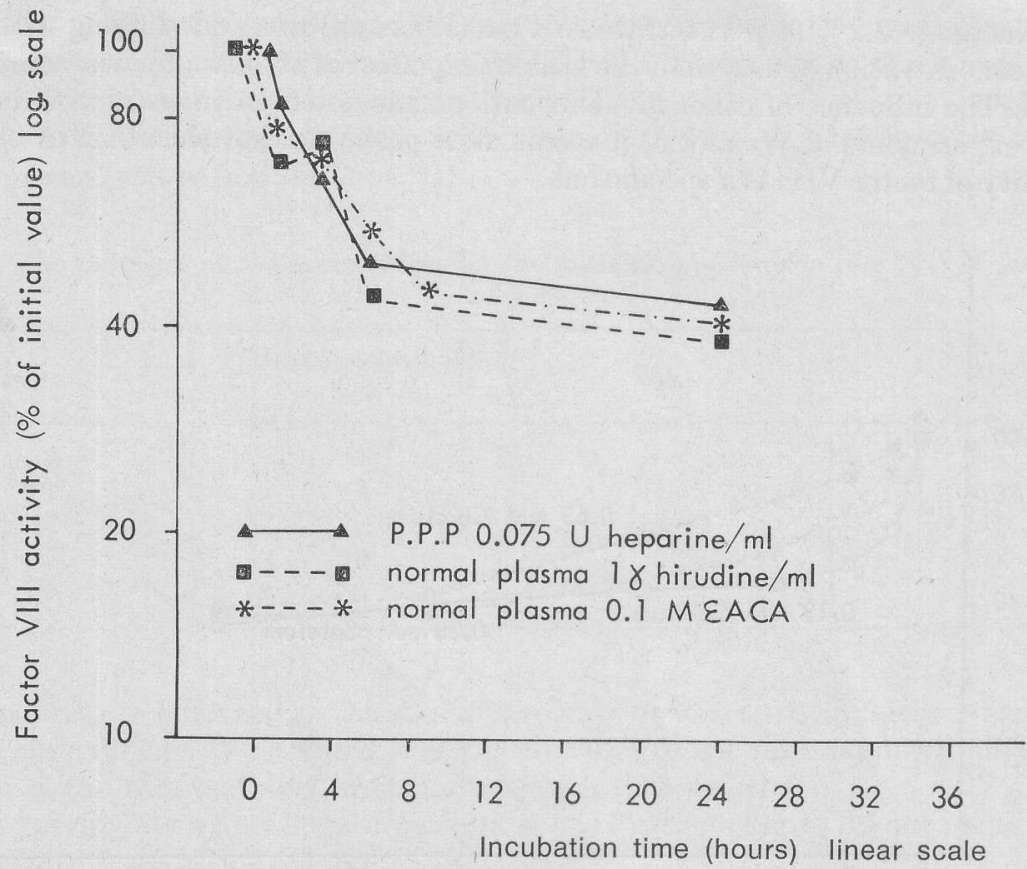

Fig. 8. Inactivation of factor VIII in platelet poor citrated plasma (PPP 500-1000 platelets $/ \mathrm{mm}^{3}$ ) with heparine $0.075 \mathrm{u} / \mathrm{ml}$, normal citrated plasma with hirudine $1 \mathrm{\gamma} / \mathrm{ml}$ and normal citrated plasma with EACA 0.1 M. Each curve is the mean of 2 experiments.

\section{Fibrinolytic System}

Addition of EACA (final concentration 0.1 M) to normal plasma did not alter the inactivation curve of factor VIII (Fig. 8). pH was not influenced by this concentration of EACA.

\section{Influence of $\mathrm{Ca}++$}

That $\mathrm{Ca}++$ improves the stability of factor VIII has been assumed for a long time (28) and was proven by Weiss in 1965 (26). The experiments of Weiss made it unlikely that another bivalent cation is of influence on the stability of factor VIII.

To investigate the role of $\mathrm{Ca}^{++}$resinblood was obtained by Fenwal Bloodpack Ion Exchange systems (type JB-2). The calcium concentration of the plasma prepared from this resinblood was $0.13 \mathrm{mM}$, so the quickly exchanging part of the protein bound calcium was also removed. The $\mathrm{pH}$ of the Resin plasma was $7.6-7.8$.

The plasma was divided into 3 parts. One part was used as such, to the other two parts $\mathrm{CaCl}_{2}\left(50 \mathrm{mM}\right.$ solution) was added so as to obtain final concentrations of $\mathrm{Ca}^{++}$of $0.38 \mathrm{mM}$ and $0.63 \mathrm{mM}$. Fig. 9 shows the results (mean of 2 experiments).

Two facts can be observed:

It is obvious that

a) increase of calcium concentration slows down the rate of inactivation of factor VIII in the first phase;

b) the level of the second phase of the curve seems to be independent of the calcium concentration. 
It seems (see Figs. 2 and 3 ) that the inactivation rate from the rapid phase as well as from the slow phase is temperature-dependent, although not as much as is described for irreversible protein denaturation processes.

The level of the slow phase differs with temperature too, it is lower as the temperature increases (compare $\mathbf{F}_{1}$ in Table 1 ).

Table 1. The influence of the temperature on the initial disappearance rate $\left(V_{1}\right)$ of factor VIII activity.

\begin{tabular}{c|c|c|c}
\hline Temp. ${ }^{\circ} \mathrm{C}$ & $\begin{array}{c}\mathrm{V}_{1} \text { disappearance rate } \\
\% / \mathrm{h}\end{array}$ & $\mathrm{Q}_{10}$ & $\mathrm{~F}_{1}$ \\
\hline 9 & 2 & - & - \\
21 & 3 & 1.43 & 35 \\
37 & 6.5 & 1.80 & 55 \\
45 & 10 & 1.82 & 65 \\
50 & 65 & 40 & \\
\hline
\end{tabular}

The curves are analysed as the sum of two exponentials, which fairly well accounts for the observations. $V_{1}$ is the initial velocity due to the first exponential. $F_{1}$ is the fraction of the total activity broken down with that velocity.

The experiments with different calcium concentration (Fig.9) do not make it likely that we have to do with a reaction of the type

$$
\begin{aligned}
& \mathrm{VIII}-\mathrm{Ca}^{++} \rightleftharpoons \mathrm{VIII}_{\mathrm{i}}+\mathrm{Ca}^{++} \\
& \left(\mathrm{VIII} \mathrm{I}_{\mathrm{i}}=\text { inactive factor } \mathrm{VIII}\right)
\end{aligned}
$$

as in this case it would be expected that the level of the second phase, which represents the equilibrium, were dependent on the $\mathrm{Ca}^{++}$concentration. It may be more probable that the $\mathrm{Ca}^{++}$influences the time at which an equilibrium is achieved between two active forms of factor VIII or between an active and an inactive form of factor VIII. If this is the case it may be possible to reactivate the factor VIII in plasma which has been incubated at low $\mathrm{Ca}^{++}$concentration by raising the calcium concentration. If factor VIII activity is caused by two independant substances - although this does not seem to be very probable in view of the results of the experiments with different temperature (see later) - it may be assumed that the substance with the highest inactivation rate is inactivated very rapidly at low calcium concentrations, while the second substance, which activity is reflected by the second phase of the curve, is not affected by the calcium concentration. Interpreting the above mentioned experiments of the influence of $\mathrm{Ca}^{++}$on the inactivation of factor VIII it must be taken into account that the influence of the $\mathrm{pH}$ on the inactivation rate of factor VIII in citrated plasma can be mediated by two mechanisms:

1. the effect of $\mathrm{H}^{+}$(resp. $\mathrm{OH}^{-}$) on the molecules with factor VIII activity;

2. effect of $\mathrm{pH}$ on the dissociation of calcium-citrate and via this way on the $\mathrm{Ca}^{++}$ concentration.

The inactivation of factor VIII in citrated plasma at temperatures between $9^{\circ} \mathrm{C}$ and $45^{\circ} \mathrm{C}$ and at $\mathrm{pH}$ between 6.4 and 8.5 can be described as biphasic. In the first $24 \mathrm{~h}$ the factor VIII activity decreases to a certain value - depending on the experimental conditions - after which the activity is fairly stable. It cannot be described as a simple exponential decrease of the factor VIII activity which means that the inactivation cannot be mediated by a reaction of the type. 


$$
\stackrel{\mathrm{K}}{\mathrm{A}} \mathrm{I}
$$

(A, A' etc. stands for active factor VIII molecules; I, I' etc. stands for inactive factor VIII molecules).

Hypotheses to explain the biphasic curve can be:

a) The presence of a substance that inactivates factor VIII in the first phase, or the generation of a substance that stabilizes factor VIII activity.

b) The existence of two independent substances with factor VIII activity with different inactivation rates.

c) Reversible denaturation of factor VIII in one or more steps.

d) Factor VIII exists in plasma in two interdependent molecular forms, one being more active than the other.

Ad a.

The experiments with plasma totally deficient in factor XII and IX excluded the influence of these factors. The influence of factor VII, X, II, V and platelets was not very probable, but could not be excluded altogether as the experiments were done in plasma that contained small amounts of these factors.

It could be excluded that inactivating substances (thrombin, intermediate products) were generated during the managing of the blood and plasma.

The transient existence, however, of an inactivating substance in the first phase or generation of a stabilizing factor in the second phase of the curve - independent of the clotting system - cannot be excluded. This substance then should also be present in haemophilic-A plasma: the hypothetical inactivating substance in fresh haemophilic A plasma, the hypothetical stabilizing factor in old haemophilic A plasma. The experiments with mixtures of normal and haemophilic A plasma gave no evidence for the existence of such a substance. This with fair probability rules out the existence of such substances.

$A d b$.

The existence of two independent substances with factor VIII activity with different inactivation rates is worth considering. The rapid phase of the curve should then represent the inactivation of both substances. The second phase, on the other hand, represents the inactivation of the most stable substance only. The activity of the latter at zero time can be found by extrapolating the line that represents the second phase of the curve towards zero-time (i.e. its intercept with the $\mathrm{Y}$ axis). At different $\mathrm{pH}$ and at different temperatures this activity at zero time must then be identical. The impression, however, is (see Figs. 4 and 2 ) that this is not the case. This makes hypothesis b less likely.

Ad c.

Protein denaturation ean be defined as the loss of one or more specific properties of the native protein. We can say then that we studied the denaturation of factor VIII, by the decline of its specific function in blood coagulation.

Protein denaturation can be described as a series of changes in the protein molecule $(8,21)$.

Somewhere in this process the specific biological activity of the protein gets lost. This may be represented as

$$
\mathrm{A} \rightleftharpoons \mathrm{A}^{\prime} \rightleftharpoons \mathrm{I} \rightleftharpoons \mathrm{I}^{\prime} \rightarrow \mathrm{I}^{\prime}
$$

Reversible protein denaturation has been described. In fact we have seen conditions that gave an increase of factor VIII activity during incubation (20). 
To explain than the biphasic inactivation of factor VIII in vitro there are several possibilities which are simplifications of this denaturation scheme.

The most simple one is

$$
A \rightarrow I
$$

As has been said, reactivation of factor VIII cannot be excluded, so we have to write

$$
\mathrm{A} \rightleftharpoons \mathrm{I}
$$

To explain the slow decrease of the second phase it must be assumed that $\mathrm{I}$ is irreversibly changed to I', the reaction $I \rightarrow I$ ' being slower than $A \rightarrow I$. The denaturation of factor VIII can be represented then as

$$
\mathrm{A} \rightleftharpoons \mathrm{I} \rightarrow \mathrm{I}^{\prime}
$$

If such an equilibrium does exist, we have to assume that it exists in vitro as well as in vivo because the half-life times in vivo and in vitro are of a comparable order of magnitude. Then the question arises why the equilibrium is changed when blood is taken from the donor. The only obvious difference is the change in $\mathrm{Ca}^{++}$concentration. As shown before, the $\mathrm{Ca}^{++}$concentration does influence the velocity with which the equilibrium is reached, but not the position of the equilibrium. The change in $\mathrm{Ca}^{++}$ concentration cannot be the sole explanation therefore of the change in the equilibrium. One has to realize, however, that in vivo factor VIII is in dynamic equilibrium with synthesis and biological turnover. This may be represented as:

$$
\begin{aligned}
\text { synthesis } \rightarrow & \mathrm{A} \rightleftharpoons \mathrm{I} \rightarrow \mathrm{I} \\
& \begin{array}{r}
\downarrow \quad \downarrow \quad \downarrow \\
\text { biological turnover. }
\end{array}
\end{aligned}
$$

When the rate of synthesis of factor VIII is of the same order of magnitude as biological turnover the reaction $\mathrm{A} \rightleftharpoons \mathrm{I}$ will not be in chemical equilibrium in vivo, but there will be an excess of $\mathrm{A}$. In vitro the reaction will approach chemical equilibrium, which we observe as the rapid phase of the disappearance curve of factor VIII activity.

If we take into account that there is some evidence that two molecular forms of factor VIII exist $(23,27)$ denaturation according tot the following scheme is an alternative possibility

$$
\mathrm{A} \rightleftharpoons \mathrm{A}^{\prime} \rightarrow \mathrm{I}
$$

In vivo this would give

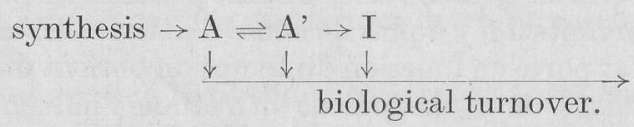

If we assume that $\mathrm{A}$ is more active than $\mathrm{A}^{\prime}$ and that in vivo there is an excess of $\mathrm{A}$ the biphasic decrease of factor VIII activity in vitro can be explained also in this way.

Ad d.

If two molecular forms of factor VIII exist in plasma they need not to be two steps in a protein denaturation process. As long as these two forms are interconvertible the same reasoning as sub $c$ is valid. They need not be in equilibrium in plasma in vivo because synthesis and breakdown in vivo can maintain a non-equilibrium steady-state. When blood is taken from the donor an equilibrium may be reached between these two molecular forms. If we assume that one form is more active than the other and that reaching the equilibrium means a decrease of the most active form the biphasic decrease of factor VIII activity in vitro can be explained. 
In conclusion the possibilities ad a and $\mathrm{b}$ are unlikely; at present we cannot differentiate experimentally between $c$ and $d$. In fact $d$ is a more general form of the mechanism discussed sub $c$.

\section{Summary}

When normal citrated plasma is stored at $37^{\circ} \mathrm{C}$ and $\mathrm{pH} .8$ the factor VIII activity drops to about $50 \%$ of its initial value during the first 8-12 h. In the following 4 days practically no further drop in activity is found. If the logarithm of the factor VIII activity is plotted against time a curve is obtained which can be described as biphasic. To explore the underlying mechanism of this phenomenon the influence of temperature, $\mathrm{pH}, \mathrm{Ca}^{++}$concentration and some other clotting factors was investigated. Between temperatures of $21^{\circ} \mathrm{C}$ and $45^{\circ} \mathrm{C}$ the inactivation of factor VIII was biphasic, the decrease of factor VIII being faster in both phases at higher temperatures. The inactivation at these temperatures showed a $Q_{10}$ of about 2 . At $52^{\circ} \mathrm{C}$ nearly all factor VIII activity disappeared within $8 \mathrm{~h}$. Possibly the precipitation of fibrinogen at this temperature is of influence. Between $\mathrm{pH} 6.4$ and 8.5 the decrease in factor VIII in the first phase was obviously slower at lower $\mathrm{pH}$ and the level of the second phase maintained at a higher factor VIII activity. No alteration of the normal inactivation pattern was seen in plasma from patients with congenital deficiencies of factors XII, IX or V or in normal plasma adsorbed with $\mathrm{BaSO}_{4}$ which has factors II, VII, IX and X markedly decreased, nor was there any difference between platelet rich and platelet poor plasma. Low calcium concentrations (Resinplasma) markedly increased the rate of inactivation in the first phase, but did not influence the second phase.

Four hypotheses are given to explain the biphasic inactivation of factor VIII: a) The presence of an inactivating substance in the first phase or a stabilizing factor in the second phase of factor VIII inactivation. b) The existence of two independent substances with factor VIII activity with different inactivation rates. c) Reversible denaturation of factor VIII in one or more steps. d) Factor VIII exists in plasma in two interdependent molecular forms. It is discussed that in view of the results of the experiments hypotheses a and b are not very likely. At present we cannot differentiate experimentally between $\mathrm{c}$ and $\mathrm{d}$.

\section{Résumé}

Quand le plasma citraté normal est conservé à $37^{\circ} \mathrm{C}$ et au pH 7.8 l'activité du facteur VIII tombe environ à $50 \%$ de sa valeur initiale pendant les premières 8 à 12 heures. Pendant les 4 jours suivants il n'y a plus de chute d'activité. Si le logarithme de l'activité du facteur VIII est porté en fonction du temps on obtient une courbe biphasique. Pour élucider le mécanisme de ce phénomène on a étudié l'influence de la température, du $\mathrm{pH}$, de la concentration de $\mathrm{Ca}^{++}$et de quelques autres facteurs de coagulation. Entre les températures de 21 et $45^{\circ} \mathrm{C}$ l'inactivation du facteur VIII est biphasique, la diminution d'activité est plus rapide dans les deux phases aux températures plus élevées. L'inactivation à ces températures a un coéfficient $\mathrm{Q}_{10}$ d'environ 2 . A $52{ }^{\circ} \mathrm{C}$ presque toute l'activité du facteur VIII disparait en 8 heures. Il est possible que la précipitation du fibrinogène à cette température joue un certain rôle. Entre les $\mathrm{pH}$ de 6.4 et 8.5 la diminution du facteur VIII dans la première phase est nettement plus lente au pH inférieur et le seuil de la seconde phase maintenu à une activité du facteur VIII plus élevée. Il n'y a pas de modification de l'inhibition dans le plasma de malades déficients en facteurs XII, IX ou V , dans le plasma normal adsorbé par $\mathrm{BaSO}_{4}$ avec une faible activité résiduelle des facteurs II, VII, IX et X. II n'y a pas non plus de différence entre les plasmas riches ou pauvres en plaquettes. Les basses concentrations 
du calcium (plasma prélevé sur résine) accélèrent la première phase d'inactivation mais n'influencent pas la seconde.

On donne 4 hypothèses susceptibles d'expliquer l'inactivation biphasique du facteur VIII : a) la présence d'une substance inactivante dans la première phase ou d'un facteur stabilisant dans la seconde. b) l'existence de deux substances indépendantes avec une activité facteur VIII et des vitesses d'inactivation différentes. c) une inactivation réversible du facteur VIII en un ou plusieurs stades, d) le facteur VIII existe dans le plasma sous deux formes moléculaires interdépendantes. Les résultats indiquent que les hypothèses a et $b$ ne sont pas très probables. Actuellement il n'est pas possible de différencier expérimentalement entre c et $\mathrm{d}$.

\section{Zusammenfassung}

Wenn normales Zitratplasma bei 37 Grad und pH 7,8 gelagert wird, fällt die Faktor-VIII-Aktivität auf ungefähr 50\% des Ausgangswertes während der ersten 8 bis 12 Stunden. In den folgenden 4 Tagen ist praktisch kein weiterer Abfall der Aktivität zu finden. Wenn der Logarhithmus der Faktor-VIII-Aktivität gegen die Zeit gezeichnet wird, so erhält man eine Kurve, die als zweiphasisch beschrieben werden kann. Um den zugrundeliegenden Mechanismus dieses Phänomens zu erforschen, wurden der Einfluß der Temperatur, des pH, der Kalziumionenkonzentration und einiger anderer Gerinnungsfaktoren untersucht. Zwischen 21 und 45 Grad ist die Inaktivierung von Faktor VIII biphasisch, wobei die Abnahme der Faktor-VIII-Aktivität in beiden Phasen bei höherer Temperatur schneller ist. Die Inaktivierung zeigt bei diesen Temperaturen ein $Q_{10}$ von ungefähr 2. Bei 52 Grad verschwand nahezu die gesamte Faktor-VIII-Aktivität innerhalb von 8 Stunden. Möglicherweise ist die Fällung des Fibrinogens bei dieser Temperatur hierfür von Bedeutung. Zwischen pH 6,4 und 8,5 war die Abnahme der Faktor-VIII-Aktivität in der ersten Phase bei niederem pH langsamer und der Spiegel der zweiten Phase blieb auf einem höheren Aktivitätsniveau. Es wurde keine Änderung der normalen Inaktivierung im Plasma von Patienten mit angeborenem Mangel an Faktor XII, IX oder V oder im bariumsulfatadsorbierten Normalplasma mit stark verminderten Faktoren II, VII, IX und X gefunden. Auch bestand kein Unterschied zwischen plättchenreichem und plättchenarmem Plasma. Niedrige Kalziumkonzentrationen (Resinplasma) steigerten die Inaktivierungsgeschwindigkeit der ersten Phase beträchtlich, hatten aber keinen Einfluß auf die zweite Phase.

Es werden 4 Hypothesen für die Erklärung der biphasischen Inaktivierung von Faktor VIII diskutiert.

a) Die Gegenwart einer inaktivierenden Substanz in der ersten Phase oder eines stabilisierenden Faktors in der zweiten Phase der Faktor-VIII-Inaktivierung.

b) Das Vorhandensein von zwei unabhängigen Substanzen mit Faktor-VIIIAktivität mit verschiedener Inaktivierungsgeschwindigkeit.

c) Reversible Denaturierung von Faktor VIII in einem oder mehreren Schritten.

d) Faktor VIII existiert im Plasma in zwei voneinander abhängigen molekularen Formen. Es wird diskutiert, daß in Anbetracht der Ergebnisse der Experimente die Hypothesen a und b nicht sehr wahrscheinlich sind. Gegenwärtig kann experimentell zwischen den Hypothesen c und d nicht unterschieden werden.

Acknowledgement

Part of this work has been carried out under the auspices of the Netherlands Foundation for Chemical Research (S.O.N.) and with financial aid from the Netherlands Organization for the Advancement of Pure Research (Z.W.O.). 


\section{References}

(1) Barrow, E. M., J. B. Graham: Von Willebrand's Disease. Progr. Hemat. 4: 203 (1964).

(2) Blombäck, M.: Purification of anti-hemophilic globulin. Archiv. Komi. 12: 387 (1958).

(3) Bounameaux, J.: Dosage des facteurs de coagulation continus dans l'atmosphère plasmatique des plaquettes humaines. Rev. franȩ. Étud. clin. biol. 2: 32 (1957).

(4) Bowie, E.J.W., J.H. Thompson, Ch. A. Owen: The stability of anti-hemophilie globulin and labile factor in human blood. Mayo Clin. Proc. 39: 145 (1964).

(5) Ellis, B. C., A. Stransky: A quick and accurate method for the determination of fibrinogen in plasma. J. Lab. clin. Med. 58: 477 (1961).

(6) Fantl, P., A. G. Marr: The preservation of coagulation factors in human plasma. Aust. J. exp. Biol. med. Sci. 34: 433 (1956).

(7) Feissley, R., H. Lüdin: Action of cocain on blood platelets. Helv. physiol. pharmacol. Acta 7: 69 (1949).

(8) Joly, M.: A physico-chemical approach to the denaturation of proteins. Academic Press, London and New York 1965.

(9) Kelowick, R.A., P.L.Walton: Studies on the purification and stability of human anti-haemophilic factor (factor VIII). Brit. J. Haemat. 11: 537 (1965).

(10) Kettenborg, H. K., S. I. de Vries, E. T. van der Pol: Modification in the behaviour of coagulation factors during storage of blood and its importance for blood transfusion. Rev. belge Path. 24: 136 (1955).

(11) Mammen, E. F.: Investigations on the nature of haemophilia-A. Thrombos. Diathes. haemorr. (Stuttg.) 9: 30 (1963).

(12) den Ottolander, G. J. H., A. Bleyenberg: Le dosage du facteur VIII. Hémostase 1: 281 (1961).

(13) Penick, G. D., K. M. Brinkhous: Relative stability of plasma Antihemophilic factor (AHF) under different conditions of storage. Amer. J. med. Sei. 232: 434 (1956).

(14) Quick, A.J.: Haemorrhagic diseases. Philadelphia, Pa 1957.

(15) Rapaport, S. J., I. Schiffman, M. J. Patch, S. B. Ames: The importance of activation of antihemophilic globulin and pro-accelerin by traces of thrombin in the generation of intrinsic prothrombinase activity. Blood 21: 221 (1963).

(16) Rapaport, S. I., S. Schiffman, S. B. Ames: Activation of antihemophilic globulin by traces of thrombin: An essential step in intrinsic prothrombinase generation. In: K. M. Brinkhous, The haemophilias. p. 49. Chapel Hill, U.S.A. 1964.

(17) Rizza, C. R., W. Walkcr: Tnactivation of AHG by thrombin. Nature (Lond.) 180: 143 (1957).

(18) Shinowara, G. Y.: Kinetic studies on the thermal denaturation of Human anti-haemophilic globulin (AHG). Thrombos. Diathes. haemorrh. (Stuttg.) 15: 636 (1966).

(19) Stibbe, J.: Experiments on the spontaneous inactivation of blood elotting factor VIII in vitro. Short Communication. Fourth meeting FEBS, Oslo 1967.

(20) Stibbe, J.: De inactivatie van factor VIII in vitro. Thesis, Amsterdam 1967.

(21) Straub, F. B.: Formation of the secondary and tertiary structure of enzymes. Advanc. Enzymol. 26: 89 (1964).

(22) Surgenor, D. M., Henry Wilson: Factor V from human plasma. Thrombos. Diathes. haemorrh. 5: $1(1960)$.

(23) Thetin, G. M., R. H. Wagner: Sedimentation of plasma antihemophilic factor. Arch. Bioch. 95: $70(1961)$.

(24) Waaler, B. A.: A simple one-stage method for the assay of anti-haemophilic-A factor. Seand. J. clin. Lab. Invest. 11: 194 (1959).

(25) Wagner, R. H., G. M. Thelin: Haemophilia and Haemophiloid Diseases. International Symposium, New York, p.3. Ed. Brinkhous, $K$. $M$. University of North Carolina Press, Chapel Hill, NC, 1957.

(26) Weiss, H. J.: A study of the cation-and $\mathrm{pH}$ dependent stability of factors $\mathrm{V}$ and VIII in plasma. Thrombos. Diathes. haemorrh. (Stuttg.) 14: 32 (1965).

(27) Weiss, H.J., J. Kochwa: Molecular forms of antihemophilic globulin in plasma, cryoprecipitate and after thrombin activation. Brit. J. Haemat. 18: 89 (1970).

(28) Wolf, P.: Studies of temperature and $\mathrm{pH}$ stability of human AHF in plasma and concentrate. Brit. J. Haemat. 5: 169 (1959).

Received for publication June 24, 1971

Copyright by F. K. Schattauer Verlag, Stuttgart - Der Verlag behält sich alle Rechte, besonders die des Nachdruckes, der Vervielfältigung und der Ubersetzung vor. 